\title{
UTILIZING SEVAP SOFTWARE TO ESTIMATE THE REFERENCE EVAPOTRANSPIRATION ON THE MINAS GERAIS STATE
}

\author{
XIMENES, Arthur Ribeiro \\ SANCHES, Fernando Mendes \\ CASTRO, Marco Aurélio de \\ CORADI, Paulo Carteri \\ CUNHA, Fernando França da
}

\begin{abstract}
SUMMARY: Reliable estimates of evapotranspiration (ET) are necessary to address different aspects related to the management of water and environmental resources. There are several models for estimating ET, each designed for different climatic conditions and which require review before being used in the new region. Therefore, this study aimed to test their different methodologies for estimate of ET in the Minas Gerais state. The methodologies tested were Hargreaves-Samani, Jensen-Haise, Linacre, Makkink and Priestley-Taylor. The meteorological data needed to perform this work were taken from Standard Climatological (1961-1990) of 50 localities of Minas Gerais, provided by the National Institute of Meteorology (Inmet). The method was taken as the standard Penman-Monteith-FAO56 and comparison of results was by the coefficient of determination $\left(\mathrm{r}^{2}\right)$, the coefficients "a" and " $b$ " of the linear regression equations, estimate of standard error (ESE), Willmott index of agreement (d), the Pearson correlation coefficient (r) and confidence coefficient (c). The SEVAP software showed simplicity in its use and accuracy in the estimate of ET in Minas Gerais state. The best methodologies for estimate of the ET in Minas Gerais were PristleyTaylor, Hargreaves-Samani and Linacre. The Hargreaves-Samani method should be preferred and used only when has data of air temperature. The methodologies Jensen-Haise and Makkink should not be used to estimate ET in Minas Gerais state.
\end{abstract}

Keywords: ET. Evaporation. Hargreaves-Samani. Penman-Monteith

\section{UTILIZAÇÃO DO SOFTWARE SEVAP PARA A ESTIMATIVA DA EVAPOTRANSPIRAÇÃO DE REFERÊNCIA NO ESTADO DE MINAS GERAIS}

\begin{abstract}
RESUMO: Estimativas confiáveis da evapotranspiração (ET) são necessárias para enfrentar diferentes aspectos relacionados ao gerenciamento dos recursos hídricos e ambientais. Existem diversos modelos de estimativa da ET, cada um concebido em condições climáticas diferentes e que necessitam de avaliação antes de serem utilizados em determinada região. Diante disso, objetivou-se nesse trabalho testar diferentes metodologias para estimativa da ET no estado de Minas Gerais. As metodologias usadas foram Hargreaves-Samani, Jensen-Haise, Linacre, Makkink e Priestley-Taylor. Os dados meteorológicos foram obtidos das normais climatológicas (1961-1990) de 50 localidades do estado de Minas Gerais, disponibilizadas pelo Instituto Nacional de Meteorologia (INMET). O método tomado como padrão foi o Penman-Monteith do boletim FAO56, e a comparação dos resultados foi por meio do coeficiente de determinação $\left(r^{2}\right)$, dos coeficientes "a" e "b" das equações de regressão linear, erro padrão da estimativa (ESE), índice de concordância de Willmott (d), coeficientes de correlação de Pearson (r) e de confiança (c). O software SEVAP apresentou simplicidade em seu uso e precisão na estimativa da ET em Minas Gerais. As melhores metodologias para estimativa da ET em Minas Gerais foram Pristley-Taylor, Hargreaves-Samani e Linacre. O método de Hargreaves-Samani deve ser preferido e, utilizado quando se dispõe apenas de dados de temperatura do ar. As metodologias de Jensen-Haise e Makkink não devem ser utilizadas para estimativa da ET em Minas Gerais.
\end{abstract}

Palavras-chave: ET. Evaporação. Hargreaves-Samani. Penman-Monteith

\section{INTRODUÇÃO}

The evapotranspiration is the simultaneous process of water loss to the atmosphere by evaporation from soil and plant transpiration. Evapotranspiration is dependent of the energy balance, of the

\footnotetext{
${ }^{1}$ Universidade Federal de Mato Grosso do Sul
} 
atmospheric demand, of the supply of water from soil to plants and of the physiological characteristics the plants. The concept of evapotranspiration (ET) according Allen et al. (1998), define ET as the evapotranspiration that occurs in a hypothetical culture, which has a fixed height of $0.12 \mathrm{~m}$, albedo equal to 0.23 and the surface resistance to transport of water vapor equal to $70 \mathrm{~s} \mathrm{~m}^{-1}$. Thus, this concept is similar to the evapotranspiration of a large green lawn of uniform height in active growth, completely covering the surface of the soil and without water limitation.

Reliable estimates of ET are necessary to address different aspects related to the management of water and environmental resources, such as public water supply, the irrigation of crops or environmental preservation of waterways. The development and application of techniques for estimating ET are important aspects of hydrological research (BIDLAKE, 2002). According to Liang; Li; Liu (2009), evapotranspiration is primarily responsible for the loss of water in the watershed, and is closely related to the dynamics of soil moisture, recharging of aquifers and surface runoff. Furthermore, the optimization and conservation of water resources are increasingly important, especially for the over-exploitation they are subjected (JENSEN et al., 1997; SANIJ; YAMAMOTO; RASIAH, 2004).

According Back (2008), ET is a parameter used in agricultural water balance and modeling of climatological and hydrological processes, in order to estimate irrigation requirements, crop forecasting, assessment of water resources availability, agroclimatic zoning and characterization of climate.

The ET can be determined in different ways. According to Burman et al. (1983), this parameter can be obtained from direct methods, including different types of lysimeters and water balance in the soil, or indirect methods involving measurements of climatic elements.

Within the direct methods for determining ET, the more accurate is the weighing lysimeter, being of high cost and restricted to research institutions for regional calibration of indirect methods. According to Jensen; Burman; Allen (1990), the indirect methods are checked models of Penman, Jensen-Haise, Priestley-Taylor, Hargreaves-Samani, Linacre, Makkink, among others, and also the evaporimeters, as the Class A pan and atmometer modified. The method based on the evaporation tanks, such as Class A, measures the effect integrated of radiation, wind speed, temperature and relative humidity over the evaporation of a surface of free-water.

There are also methods for estimating ET by the meteorological elements that feed empirical equations and/or with physical fundamentation. Many of these methods have variants, for issues of local adjustments and local calibrations, further increasing the amount of available methods (CARVALHO et al., 2011).

The method of Penman-Monteith-FAO56 (ALLEN et al., 1998) according to various studies, in Brazil and in the world, is quite accurate (XU; CHEN, 2005; YODER; ODHIAMBO; WRIGHT, 2005; LÓPEZ-URREA et al., 2006; JABLOUN; SAHLI, 2008; BARROS et al., 2009) being thence, widely used as a standard for comparison with other methods. According to Allen et al. (1998), this model provides reliable and consistent estimates of ET because it associates the effects of energy balance and aerodynamic terms in estimating evapotranspiration. Doorenbos; Pruitt (1977) modified the equation of Penman (1963), giving greater sensitivity due to the wind, adjusting the correction factor FAO (c), based on local weather conditions and assuming flux density heat the ground (G) equal to zero at times daily. According to Cavalcante Jr. et al. (2011), despite the Penman-Monteith-FAO56 ET estimate satisfactorily, often not all meteorological elements required for use of this model are available. In this scenario, other methods that require fewer meteorological elements can be used.

The Hargreaves-Samani method is derived from the Hargreaves method that was developed in Davis, California based on a study of grass in lysimeters. This method was developed for regions where 
the availability of climatological data was limited (JACOBS; SATTI, 2001), requiring measures terrestrial radiation and maximum and minimum temperatures. In 1985, Hargreaves and Samani simplified this formula where only measures temperature maximum and minimum (PEREIRA; VILLA NOVA; SEDIYAMA, 1997). The Jensen-Haise method is simple and based only on daily values of mean temperature and solar radiation. The Linacre method was developed in 1977 and based on correlations founds between the various meteorological factors, simplified the Penman equation estimating the potential evaporation and potential evapotranspiration just based on geographical data (latitude and altitude) and air temperature (DOLAN et al., 1984). The Makkink method is derived from the PenmanMonteith and was developed for climate conditions of Wageningem, the Netherlands, requiring the following input parameters: slope of the pressure curve, psychrometric coefficient and global radiation (BERLATO; MOLION, 1981). The Priestley-Taylor equation was developed in 1972 and simulates the evaporation surfaces in a saturated atmosphere not saturated, which is the normal condition of nature. The input parameters are slope of the pressure curve, psychrometric coefficient and net radiation (BERLATO; MOLION, 1981).

Due to the complexity of many equations for estimation of ET and urgency of implementing new strategies of information seeking on the area of water and environmental resources, there is demand of use of models more simple and accessible.

Minas Gerais is one of the largest states, in area size, and agricultural producer in the country. Therefore, this state has several hydro-agricultural projects that require fast and reliable estimates of ET. Despite the existence of many estimates of ET, these, however, are used in very different climatic and agronomic conditions from those that were originally designed and therefore is of utmost importance to assess the degree of accuracy of these models, before use them to new condition. Several studies comparing the various methods for estimating ET are found in the literature for different regions (ARAÚJO; COSTA; SANTOS, 2007; BACK, 2008; SYPERRECK et al., 2008; BARROS et al., 2009; KISI, 2009; PEREIRA et al., 2009; CAVALCANTE Jr. et al., 2011; KISI; ALI BABA; SHIRI, 2012; MAGALHÃES; CUNHA, 2012; SAHOO et al., 2012; CUNHA; MAGALHÃES; CASTRO, 2013). Thus, this research aims to test five methodologies for estimating evapotranspitaion for the of Minas Gerais state.

\section{MATERIAL AND METHODS}

Among the methods for estimating evapotranspiration (ET) contained in SEVAP software, was tested in the methodologies Hargreaves-Samani, Jensen-Haise, Linacre, Makkink and Priestley-Taylor (SILVA et al., 2005). Table 1 shows the input parameters for the five models tested and to the method of Penman-Monteith-FAO56 (ALLEN et al., 1998), which was taken as the standard for estimating ET, following recommendations from the FAO-56.

Table 1. Input parameters for estimating evapotranspiration (ET) for different models of PenmanMonteith used by SEVAP software.

\begin{tabular}{|c|c|c|c|c|c|c|}
\hline \multirow{2}{*}{ Methods } & \multicolumn{6}{|c|}{ Input Parameters Measured } \\
\hline & $\mathrm{T}_{\max }\left({ }^{\circ} \mathrm{C}\right)$ & $\mathrm{T}_{\min }\left({ }^{\circ} \mathrm{C}\right)$ & n (hours) & $\mathrm{RH}(\%)$ & $\mathrm{U}_{2}\left(\mathrm{~m} \mathrm{~s}^{-1}\right)$ & $\mathrm{P}_{\mathrm{atm}}(\mathrm{hPa})$ \\
\hline Penman-Monteith & $\mathrm{X}$ & $\mathrm{x}$ & $\mathrm{X}$ & $\mathrm{x}$ & $\mathrm{x}$ & $\mathrm{x}$ \\
\hline Hargreaves-Samani & $\mathrm{x}$ & $\mathrm{x}$ & & & & \\
\hline Jensen-Haise & $\mathrm{x}$ & $\mathrm{x}$ & $\mathrm{x}$ & & & \\
\hline Linacre & $\mathrm{x}$ & $\mathrm{X}$ & & $\mathrm{x}$ & & \\
\hline Makkink & $\mathrm{x}$ & $\mathrm{X}$ & $\mathrm{x}$ & & & \\
\hline Priestley-Taylor & $\mathrm{x}$ & $\mathrm{x}$ & $\mathrm{x}$ & & & \\
\hline
\end{tabular}


The meteorological data needed to perform this work were obtained from normal climatological (1961-1990) of 50 locations in the Minas Gerais state, provided by the National Institute of Meteorology. The geographical coordinates of meteorological stations are shown in Table 2.

Table 2. Information of the Minas Gerais state weather stations used to estimate evapotranspiration (ET) by SEVAP software.

\begin{tabular}{|c|c|c|c|}
\hline Locality & $\begin{array}{c}\text { Latitude } \\
\text { (degrees: min) }\end{array}$ & $\begin{array}{c}\text { Longitude } \\
\text { (degrees: min) }\end{array}$ & $\begin{array}{l}\text { Altitude } \\
\text { (meters) }\end{array}$ \\
\hline Aimorés & $19^{\circ} 29^{\prime} \mathrm{S}$ & $41^{\circ} 04^{\prime} \mathrm{W}$ & 82.7 \\
\hline Araçuaí & $16^{\circ} 50^{\prime} \mathrm{S}$ & $42^{\circ} 03^{\prime} \mathrm{W}$ & 289.0 \\
\hline Araxá & $19^{\circ} 36^{\prime} \mathrm{S}$ & $46^{\circ} 56^{\prime} \mathrm{W}$ & 1023.6 \\
\hline Belo Horizonte & $19^{\circ} 56^{\prime} \mathrm{S}$ & $43^{\circ} 56^{\prime} \mathrm{W}$ & 915.0 \\
\hline Poços de Caldas & $21^{\circ} 55^{\prime} \mathrm{S}$ & $46^{\circ} 23^{\prime} \mathrm{W}$ & 1150.0 \\
\hline Cambuquira & $21^{\circ} 51^{\prime} \mathrm{S}$ & $45^{\circ} 18^{\prime} \mathrm{W}$ & 950.1 \\
\hline Capinópolis & $18^{\circ} 43^{\prime} \mathrm{S}$ & $49^{\circ} 33^{\prime} \mathrm{W}$ & 620.6 \\
\hline Caratinga & $19^{\circ} 48^{\prime} \mathrm{S}$ & $42^{\circ} 09^{\prime} \mathrm{W}$ & 609.7 \\
\hline Cataguases & $21^{\circ} 23^{\prime} \mathrm{S}$ & $42^{\circ} 41^{\prime} \mathrm{W}$ & 168.0 \\
\hline Caxambu & $21^{\circ} 58^{\prime} \mathrm{S}$ & $44^{\circ} 56^{\prime} \mathrm{W}$ & 958.5 \\
\hline Conceição do Mato Dentro & $19^{\circ} 01 ' \mathrm{~S}$ & $43^{\circ} 26^{\prime} \mathrm{W}$ & 652.0 \\
\hline Coronel Pacheco & $21^{\circ} 34^{\prime} \mathrm{S}$ & $43^{\circ} 15^{\prime} \mathrm{W}$ & 435.0 \\
\hline Curvelo & $18^{\circ} 45^{\prime} \mathrm{S}$ & $44^{\circ} 27^{\prime} \mathrm{W}$ & 672.0 \\
\hline Diamantina & $18^{\circ} 15^{\prime} \mathrm{S}$ & $43^{\circ} 36^{\prime} \mathrm{W}$ & 1296.1 \\
\hline Espinosa & $14^{\circ} 55^{\prime} \mathrm{S}$ & $42^{\circ} 51^{\prime} \mathrm{W}$ & 569.6 \\
\hline Florestal & $19^{\circ} 53 ' \mathrm{~S}$ & $44^{\circ} 25^{\prime} \mathrm{W}$ & 753.0 \\
\hline Formoso & $14^{\circ} 56^{\prime} \mathrm{S}$ & $46^{\circ} 15^{\prime} \mathrm{W}$ & 840.0 \\
\hline Frutal & $20^{\circ} 02^{\prime} \mathrm{S}$ & $48^{\circ} 56^{\prime} \mathrm{W}$ & 543.7 \\
\hline Governador Valadares & $18^{\circ} 51 ' \mathrm{~S}$ & $41^{\circ} 56^{\prime} \mathrm{W}$ & 148.0 \\
\hline Ibirité & $20^{\circ} 01 ' \mathrm{~S}$ & $44^{\circ} 03^{\prime} \mathrm{W}$ & 814.5 \\
\hline Itamarandiba & $17^{\circ} 51 ' \mathrm{~S}$ & $42^{\circ} 51^{\prime} \mathrm{W}$ & 1097.0 \\
\hline Itambacuri & $18^{\circ} 01^{\prime} \mathrm{S}$ & $41^{\circ} 01^{\prime} \mathrm{W}$ & 285.4 \\
\hline Januária & $15^{\circ} 27^{\prime} \mathrm{S}$ & $44^{\circ} 22^{\prime} \mathrm{W}$ & 473.7 \\
\hline João Monlevade & $19^{\circ} 50^{\prime} \mathrm{S}$ & $43^{\circ} 07^{\prime} \mathrm{W}$ & 859.8 \\
\hline João Pinheiro & $17^{\circ} 42^{\prime} \mathrm{S}$ & $46^{\circ} 10^{\prime} \mathrm{W}$ & 760.4 \\
\hline Juiz de Fora & $21^{\circ} 46 ' \mathrm{~S}$ & $43^{\circ} 21^{\prime} \mathrm{W}$ & 940.0 \\
\hline Lavras & $21^{\circ} 45^{\prime} \mathrm{S}$ & $45^{\circ} 00^{\prime} \mathrm{W}$ & 918.8 \\
\hline Machado & $21^{\circ} 39^{\prime} \mathrm{S}$ & $45^{\circ} 54^{\prime} \mathrm{W}$ & 873.4 \\
\hline Minas Novas & $17^{\circ} 14^{\prime} \mathrm{S}$ & $42^{\circ} 35^{\prime} \mathrm{W}$ & 920.8 \\
\hline Monte Azul & $15^{\circ} 05^{\prime} \mathrm{S}$ & $42^{\circ} 45^{\prime} \mathrm{W}$ & 603.6 \\
\hline Montes Claros & $16^{\circ} 41 ' \mathrm{~S}$ & $43^{\circ} 50^{\prime} \mathrm{W}$ & 646.3 \\
\hline Oliveira & $20^{\circ} 41 ' \mathrm{~S}$ & $44^{\circ} 49^{\prime} \mathrm{W}$ & 966.5 \\
\hline Ouro Fino & $22^{\circ} 17 ' \mathrm{~S}$ & $46^{\circ} 22^{\prime} \mathrm{W}$ & 925.7 \\
\hline Paracatu & $17^{\circ} 14^{\prime} \mathrm{S}$ & $46^{\circ} 53^{\prime} \mathrm{W}$ & 712.0 \\
\hline Passa Quatro & $22^{\circ} 23^{\prime} \mathrm{S}$ & $44^{\circ} 58^{\prime} \mathrm{W}$ & 920.0 \\
\hline Patos de Minas & $18^{\circ} 31 ' S$ & $46^{\circ} 26^{\prime} \mathrm{W}$ & 940.3 \\
\hline Patrocínio & $18^{\circ} 57^{\prime} \mathrm{S}$ & $47^{\circ} 00^{\prime} \mathrm{W}$ & 934.0 \\
\hline Pedra Azul & $16^{\circ} 00^{\prime} \mathrm{S}$ & $41^{\circ} 17^{\prime} \mathrm{W}$ & 648.9 \\
\hline Pirapora & $17^{\circ} 21^{\prime} \mathrm{S}$ & $44^{\circ} 55^{\prime} \mathrm{W}$ & 505.2 \\
\hline Pompeu & $19^{\circ} 13^{\prime} \mathrm{S}$ & $45^{\circ} 00^{\prime} \mathrm{W}$ & 690.9 \\
\hline Salinas & $16^{\circ} 10^{\prime} \mathrm{S}$ & $42^{\circ} 18^{\prime} \mathrm{W}$ & 471.3 \\
\hline São Francisco & $15^{\circ} 57^{\prime} \mathrm{S}$ & $44^{\circ} 52^{\prime} \mathrm{W}$ & 446.5 \\
\hline São João del-Rei & $21^{\circ} 18^{\prime} \mathrm{S}$ & $44^{\circ} 16^{\prime} \mathrm{W}$ & 991.0 \\
\hline São Lourenço & $22^{\circ} 06 ' \mathrm{~S}$ & $45^{\circ} 01^{\prime} \mathrm{W}$ & 953.2 \\
\hline São Sebastião do Paraíso & $20^{\circ} 55^{\prime} \mathrm{S}$ & $47^{\circ} 07^{\prime} \mathrm{W}$ & 820.0 \\
\hline Sete Lagoas & $19^{\circ} 28^{\prime} \mathrm{S}$ & $44^{\circ} 15^{\prime} \mathrm{W}$ & 732.0 \\
\hline Teófilo Otoni & $17^{\circ} 51 ' \mathrm{~S}$ & $41^{\circ} 30^{\prime} \mathrm{W}$ & 356.4 \\
\hline Uberaba & $19^{\circ} 44^{\prime} \mathrm{S}$ & $47^{\circ} 57^{\prime} \mathrm{W}$ & 737.0 \\
\hline Usiminas & $19^{\circ} 29^{\prime} \mathrm{S}$ & $42^{\circ} 32^{\prime} \mathrm{W}$ & 298.6 \\
\hline Viçosa & $20^{\circ} 45^{\prime} \mathrm{S}$ & $42^{\circ} 51^{\prime} \mathrm{W}$ & 689.7 \\
\hline
\end{tabular}

Nucleus,v.12,n.1,abr.2015 
The ET obtained by the proposed method by Penman-Monteith-FAO56 (ALLEN et al., 1998) was calculated according to the following equations:

$$
\begin{aligned}
& \mathrm{ET}=\frac{0.408 \Delta\left(\mathrm{R}_{\mathrm{N}}-\mathrm{G}\right)+\gamma \frac{900}{\mathrm{t}+273} \mathrm{U}_{2} \frac{\left(\mathrm{e}_{\mathrm{S}}-\mathrm{e}\right)}{10}}{\Delta+\gamma\left(1+0.34 \mathrm{U}_{2}\right)} \\
& \mathrm{R}_{\mathrm{N}}=\mathrm{Rns}+\mathrm{Rnl} \\
& \mathrm{Rns}=\mathrm{R}_{\mathrm{S}}(1-\alpha) \\
& \mathrm{Rnl}=4.898910^{-9} \mathrm{~T}^{4}(0.09 \sqrt{0.75 \mathrm{e}}-0.56)\left(0.1+0.9 \frac{\mathrm{n}}{\mathrm{N}}\right) \\
& \mathrm{R}_{\mathrm{S}}=\mathrm{R}_{\mathrm{a}}\left(\mathrm{a}+\mathrm{b} \frac{\mathrm{n}}{\mathrm{N}}\right) \\
& \mathrm{R}_{\mathrm{a}}=37.6 \mathrm{~d}_{\mathrm{r}}\left[\frac{\pi}{180} \mathrm{w}_{\mathrm{s}} \operatorname{sen} \varphi \operatorname{sen} \delta+\cos \varphi \cos \delta \operatorname{sen} \mathrm{w}_{\mathrm{s}}\right] \\
& \mathrm{a}=0.29 \cos \varphi \\
& \mathrm{b}=0.52 \\
& \mathrm{~N}=\frac{2 \mathrm{w}_{\mathrm{s}}}{15} \\
& \mathrm{~d}_{\mathrm{r}}=1+0.033 \cos \left(\frac{360 \mathrm{j}}{365}\right) \\
& \mathrm{w}_{\mathrm{s}}=\arccos [-\operatorname{tag} \varphi \operatorname{tag} \delta] \\
& \delta=23.45 \operatorname{sen}\left[\frac{360}{365}(284+\mathrm{j})\right] \\
& \mathrm{e}=\frac{\mathrm{RH}}{100} \mathrm{e}_{\mathrm{s}} \\
& e_{S}=6.107810^{\left(\frac{7.5 t}{237.3+t}\right)} \\
& \Delta=\frac{409.8 \mathrm{e}_{\mathrm{S}}}{(237.3+\mathrm{t})^{2}} \\
& \mathrm{G}=0.05 \mathrm{R}_{\mathrm{N}} \\
& \gamma=162.86 \frac{\mathrm{P}}{\lambda} \\
& \lambda=2.510^{6}-2.370 \mathrm{t} \\
& \mathrm{U}_{2}=\frac{4.868}{\ln (67.75 \mathrm{z}-5.42)} \mathrm{U}_{\mathrm{z}}
\end{aligned}
$$

where: ET = evapotranspiration of the Penman-Monteith, $\mathrm{mm}_{\text {day }}{ }^{-1} ; \Delta=$ slope vapour pressure curve, $\mathrm{kPa}$ ${ }^{\circ} \mathrm{C}^{-1} ; \mathrm{R}_{\mathrm{N}}=$ net radiation at the crop surface, $\mathrm{MJ} \mathrm{m}^{-2} \mathrm{day}^{-1} ; \gamma=$ psychrometric constant, $\mathrm{kPa}^{\circ} \mathrm{C}^{-1} ; \mathrm{t}=$ mean daily air temperature at $2 \mathrm{~m}$ height, ${ }^{\circ} \mathrm{C} ; \mathrm{U}_{2}=$ wind speed at $2 \mathrm{~m}$ height, $\mathrm{m} \mathrm{s}^{-1} ; \mathrm{e}_{\mathrm{S}}=$ saturation vapour pressure, $\mathrm{hPa} ; \mathrm{e}=$ actual vapour pressure, $\mathrm{hPa} ; \mathrm{Rns}=$ net solar or shortwave radiation, $\mathrm{MJ} \mathrm{m}^{-2} \mathrm{day}^{-1} ; \mathrm{Rnl}=$ 
net longwave radiation, $\mathrm{MJ} \mathrm{m}^{-2}$ day $^{-1} ; \mathrm{R}_{\mathrm{S}}=$ solar or shortwave radiation, $\mathrm{MJ} \mathrm{m}^{-2}$ day $^{-1} ; \alpha=$ albedo or canopy reflection coefficient, dimensionless; $\mathrm{T}=$ average daily temperature of the air, $\mathrm{K} ; \mathrm{n}=$ actual duration of sunshine, hour; $\mathrm{N}=$ maximum possible duration of sunshine, hour; $\mathrm{R}_{0}=$ extraterrestrial radiation, $\mathrm{MJ} \mathrm{m}^{-2}$ day $^{-1}$; a e $\mathrm{b}=$ fraction of extraterrestrial radiation reaching the earth on clear-sky days, dimensionless; $d_{R}=$ inverse relative distance Earth-Sun, dimensionless; $\mathrm{w}_{\mathrm{s}}=$ sunset hour angle, degrees; $\varphi$ $=$ latitude, degrees; $\delta=$ solar declination, degrees; $\mathrm{j}=$ number of the day in the year between 1 ( 1 January) and 365 or 366 (31 December); RH = relative humidity, $\% ; \mathrm{G}=$ soil heat flux, $\mathrm{MJ} \mathrm{m}^{-2} \mathrm{day}^{-1} ; \mathrm{P}=$ atmospheric pressure, $\mathrm{hPa} ; \lambda=$ latent heat of vaporization, $\mathrm{J} \mathrm{kg}^{-1} ; \mathrm{U}_{\mathrm{z}}=$ wind speed at " $\mathrm{z}$ " $\mathrm{m}$ above ground surface, $\mathrm{m} \mathrm{s}^{-1} ; \mathrm{z}=$ height of wind measurements, $\mathrm{m}$.

After obtaining the daily ET through different methodologies it was conducted a regression analysis that correlated the ET values estimated by empirical equations of the SEVAP software with the Penman-Monteith (ALLEN et al., 1998). It was considered the coefficients "a" and "b" of the respective linear regressions and the coefficient of determination $\left(\mathrm{r}^{2}\right)$. The best alternative was the one that showed regression coefficient "a" near to zero, coefficient " $b$ " near the unity, and coefficient of determination more than 0.70 . The precision was measured through the coefficient of determination, which indicates the degree to which the regression explains the sum of the total squared.

Performance analysis of methods was done comparing the ET values obtained by empirical methods with the Penman-Monteith-FAO56 (ALLEN et al., 1998). The methodology adopted for comparison of results was proposed by Allen et al. (1989), and is based on the estimate of standard error (ESE), calculated by Equation 20. The best method to estimate ET was the one that presented the lowest ESE.

$\mathrm{ESE}=\left[\frac{\sum_{\mathrm{i}=1}^{\mathrm{n}}\left(\mathrm{X}_{\mathrm{i}}-\mathrm{Y}_{\mathrm{i}}\right)^{2}}{\mathrm{n}}\right]^{1 / 2}$

where: $\mathrm{ESE}=$ estimate of standard error, $\mathrm{mm} \mathrm{day}^{-1} ; \mathrm{X}_{\mathrm{i}}=$ evapotranspiration estimated by the standard method, $\mathrm{mm} \mathrm{day}^{-1} ; \mathrm{Y}_{\mathrm{i}}=$ evapotranspiration obtained through the tested method, $\mathrm{mm} \mathrm{day}^{-1} ; \mathrm{n}=$ number of observations.

The approximation of ET values estimated by the method studied, in relation to the values obtained using the standard method, was obtained by an concordance index (d) (WILLMOTT et al., 1985), where its values range from zero - where there is no concordance, to 1 - for the perfect concordance. The concordance index (d) was calculated using the Equation 21. To validate the model, it was also obtained the Pearson's correlation coefficient (r) through Equation 22 and the performance coefficient (c) through Equation 23.

$d=1-\frac{\sum_{i=1}^{n}\left(X_{i}-Y_{i}\right)^{2}}{\sum_{i=1}^{n}\left[\left(\left|X_{i}-\bar{Y}\right|\right)+\left(\left|Y_{i}-\bar{Y}\right|\right)\right]^{2}}$ 


$$
\begin{aligned}
& r=\frac{\sum_{i=1}^{n}\left(\left|Y_{i}-\bar{Y}\right|\right)\left(\left|X_{i}-\bar{X}\right|\right)}{\sqrt{\sum_{i=1}^{n}\left(Y_{i}-\bar{Y}\right)^{2}} \sqrt{\sum_{i=1}^{n}\left(X_{i}-\bar{X}\right)^{2}}} \\
& c=r d
\end{aligned}
$$

where: $d=$ Willmott's concordance index; $X_{i}=$ evapotranspiration estimated through the standard method, $\mathrm{mm}$ day $^{-1} ; \mathrm{Y}_{\mathrm{i}}=$ evapotranspiration obtained through the tested method, $\mathrm{mm} \mathrm{day}^{-1} ; \overline{\mathrm{Y}}=$ average values of evapotranspiration obtained through the method method, $\mathrm{mm}$ day $^{-1} ; \overline{\mathrm{X}}=$ average values of evapotranspiration obtained through standard method, $\mathrm{mm} \mathrm{day}^{-1} ; \mathrm{n}=$ number of observations; $\mathrm{r}=$ Pearson's correlation coefficient; $\mathrm{c}=$ performance coefficient.

According to Cohen (1988), the correlation coefficient (r) can be classified as: "very low" ( $\mathrm{r}<$ $0.1)$, "low" $(0.1<\mathrm{r}<0.3)$, "moderate" $(0.3<\mathrm{r}<0.5)$; "high" $(0.5<\mathrm{r}<0.7)$; "very high" $(0.7<\mathrm{r}<0.9)$; and "almost perfect" $(r>0.9)$.

The coefficient "c", proposed by Camargo; Sentelhas (1997), is interpreted in accordance with authors such as: "great" (c $>0.85)$; "very good" $(0.76<\mathrm{c}<0.85)$; "good" $(0.66<\mathrm{c}<0.75)$, "average" $(0.61<\mathrm{c}<0.65)$, "badly" $(0.51<\mathrm{c}<0.60)$, "not good" $(0.41<\mathrm{c}<0.50)$ and "terrible" $(\mathrm{c}<0.40)$.

\section{RESULTS AND DISCUSSION}

In Figure 1 are shown graphs and models resulting of the linear regression being considering the methods for estimating evapotranspiration (ET) used in the analysis with the Penman-Monteith standard. It is observed, on the basis of the regression lines, the method of Jensen-Haise underestimated and the method of Makkink overestimated the ET values. These results agree with some studies in the literature. Mendonça et al. (2003) found underestimation of ET with the method of Jensen-Haise in the Northern Fluminense on the State of Rio de Janeiro. Magalhães; Cunha (2012) found overestimation of ET by Makkink method in Mato Grosso do Sul state. Is observed also in Figure 1 that the method of the Hargreaves-Samani, Linacre and Priestley-Taylor underestimated the ET values only when the PenmanMonteith-FAO56 accused estimates above $4.4 \mathrm{~mm}_{\text {day }}{ }^{-1}$. Cunha; Magalhães; Castro (2013) evaluating the performance of these methods on Chapadão do Sul-MS, observed that the Hargreaves-Samani and Priestley-Taylor methods underestimated the ET values only when the standard method accused estimates exceeding 5.5 and $3.0 \mathrm{~mm} \mathrm{day}^{-1}$, respectively. Have the method of Linacre, according to the authors, stood out with high regression coefficients "a" and "b", ie, this method overestimated ET values over the standard method. 
Figure 1. Values of evapotranspiration (ET) obtained by the Penman-Monteith-FAO56 compared with ET values obtained by SEVAP through the equations of Hargreaves-Samani, Jensen-Haise, Linacre, Makkink and Priestley-Taylor.
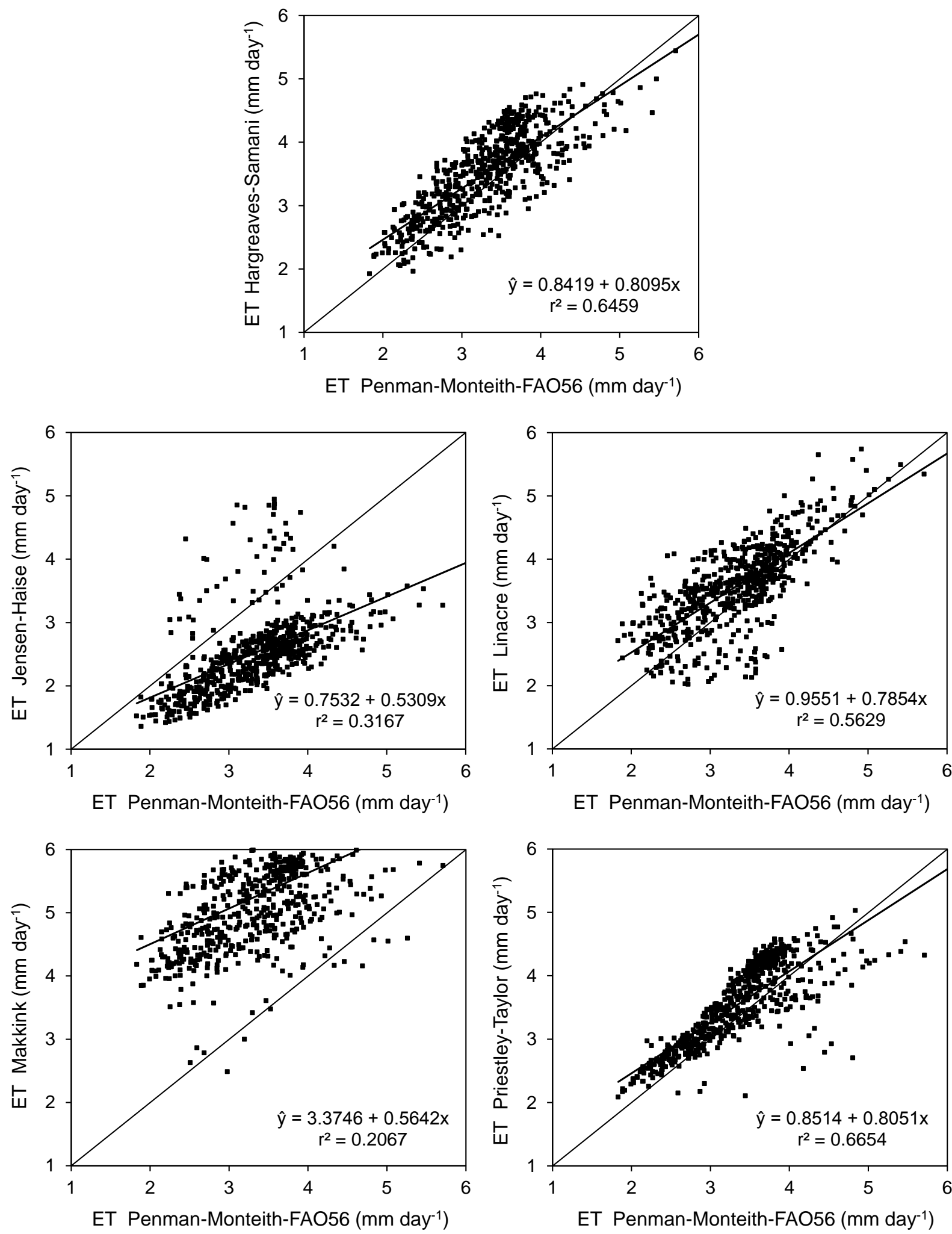
The worst fits of the regression equations to determine ET, according to the coefficient of determination $\left(r^{2}\right)$ were observed in methods of Makkink $\left(r^{2}=0.2067\right)$ and Jensen-Haise $\left(r^{2}=0.3167\right)$, which corrobora with Magalhães; Cunha (2012) evaluated this method in the Mato Grosso do Sul state.

The best fit was found using the method of Priestley-Taylor $\left(r^{2}=0.6654\right)$. This method showed the best combination of regression coefficients "a" and "b", so that the "a" coefficient approached zero and the coefficient " $b$ " the unit. The Priestley-Taylor method according to Berlato; Molion (1981) simulates the evaporation of surfaces saturated on the atmosphere not saturated, which is the normal condition of nature. Marcuzzo; Arantes; Wendland (2008) in the São Paulo state, and Magalhães; Cunha (2012) in Mato Grosso do Sul state, also found good fits of the regression equations relating the estimates of ET with the methods of Penman-Monteith-FAO56 and Priestley-Taylor.

On the Table 3 are presents the estimate of standard error (ESE), Willmott concordance index (d), the Pearson's correlation (r), performance coefficient (c) of Camargo; Sentelhas (1997) obtained by correlations between the ET values by Penman-Monteith-FAO56 with the methodologies contained in SEVAP software. It is observed that Priestley-Taylor was the model with the performed better, according to Camargo; Sentelhas (1997), to estimate ET in Minas Gerais state. This model showed a correlation coefficient (r) rated "very high", according to Cohen (1988). Also, was the model that had the lowest ESE and higher concordance Willmott, confirming its best performance compared to the other methods. Braganza et al. (2010) in the Espírito Santo state, Tagliaferre et al. (2010) in Eunápolis-BA, Silva et al. (2011) in Uberlândia-MG, and Magalhães; Cunha (2012) in Mato Grosso do Sul state also observed good performance of the Priestley-Taylor method to estimate the daily ET.

$\mathrm{Xu}$; Chen (2005) evaluated in Germany seven methods for the estimation of ET, among them, Priestley-Taylor, comparing them with data from a weighing lysimeter. The authors concluded that this method has achieved good results, with one error below 10\%. This methodology is based on net radiation and has been used in many studies because of its simplicity compared to the combined methods, does not require data of wind speed and air relative humidity.

Table 3. Estimate of standard error (ESE), Willmott's concordance index (d), the Pearson's correlation (r), performance coefficient (c) of Camargo and Sentelhas obtained correlations between the values of evapotranspiration (ET) by the method Penman-Monteith-FAO56 with those obtained by SEVAP software, with equations of Hargreaves-Samani, Jensen-Haise, Linacre, Makkink and Priestley-Taylor.

\begin{tabular}{lcccccl}
\hline \multicolumn{1}{c}{ Methods } & ET & ESE & $\mathrm{d}$ & $\mathrm{r}$ & $\mathrm{c}$ & Performance \\
\hline Penman-Monteith-FAO56 & 3.3317 & - & - & - & - & - \\
SEVAP-Hargreaves-Samani & 3.5388 & 0.4582 & 0.8707 & 0.8483 & 0.7386 & Good \\
SEVAP-Jensen-Haise & 2.5221 & 1.0026 & 0.5851 & 0.6914 & 0.4046 & Terrible \\
SEVAP-Linacre & 3.5719 & 0.5286 & 0.8360 & 0.8293 & 0.6933 & Good \\
SEVAP-Makkink & 5.2543 & 2.0718 & 0.3500 & 0.6777 & 0.2372 & Terrible \\
SEVAP-Priestley-Taylor & 3.5339 & 0.4411 & 0.8776 & 0.8671 & 0.7609 & Very Good \\
\hline
\end{tabular}

Hargreaves-Samani and Linacre methods, according to Camargo; Sentelhas (1997), received performance rated as "good" (Table 3). The Hargreaves-Samani method showed a correlation coefficient with rating "very high". The method of Hargreaves-Samani stands out for being more simple and easy to apply, requiring only temperature data and latitude of the location. Thus, by requiring only data temperature maximum and minimum, should be preferred for reliable estimation of ET in Minas Gerais. It is worth mentioning that the Priestley-Taylor method despite its better performance of Camargo; Sentelhas (1997) presented coefficient of confidence only $2.9 \%$ over the method of Hargreaves-Samani. Added to this, requires more complex data, such as terrestrial radiation and duration solar brightness for entry on the 
SEVAP software. It is worth mentioning that the Priestley-Taylor method, despite its better performance on this study, Hargreaves-Samani not estimated accurately the ET in some Brazilian regions, such as and Oliveira et al. (2008) in Viçosa-MG, Reis; Bragança; Garcia (2007) on Venda Nova do ImigrantesES, Braganza et al. (2010) in Cachoeiro do Itapemerim-ES, Sooretama-ES and Venda Nova-ES, Tagliaferre et al. (2010) and Eunápolis-BA, Alencar et al. (2011) in Uberaba-MG. Barros et al. (2009) evaluating the method of Hargreaves-Samani on the region of Seropédica-RJ found no good estimates of daily ET. The authors recommend this method only for average estimates from 3 days. Back (2008) observed poor performance of Hargreaves-Samani in estimate of ET in Urussanga-SC, it was developed for the semi-arid conditions.

The methodology of Linacre received performance rated as "good", and can also be used in the Minas Gerais state. However, this method has the disadvantage, compared to the method of HargreavesSamani, of requiring the calculation of dew point temperature by the relative humidity, which can be obtained by means of a term-higrógrafo. This method is derived from the Penman method, and also requires geographic data (latitude and altitude) and mean air temperature. Pereira et al. (2009) in the Serra da Mantiqueira-MG and Mendonça; Dantas (2010) in Capim-PB found no good estimates of ET by this method in these regions, and blamed this performance by disregarding radiation and wind speed.

The methodologies of Jensen-Haise and Makkink obtained low correlation coefficients, and received according to Camargo; Sentelhas (1997), performance rated as "terrible" (Table 3). The JensenHaise method showed high value of ESE, received "high" rating for the correlation coefficient, but low value of Willmott's concordance. Besides the low performance, this methodology requires radiation data, which hinders its use. According to Cavalcante Jr. et al. (2011), the equation of Jensen-Haise, the same way that the Hargreaves-Samani equation was developed for arid and semi-arid, and with this, has good adaptability to the dry period. Silva et al. (2005) also confirms that the methodology of Jensen-Haise is suitable for arid and semi-arid, and with this, it should fit well to the north of Minas Gerais state. Souza et al. (2011) evaluating the method of Jensen-Haise in Seropédica-RJ also did not found a perform well in the estimation of ET. The authors have shown through their results, that the confidence in the use of this method must be reduced with increase cloudiness on the day of the estimate, ie, with the atmospheric transmissivity decrease. Magalhães; Cunha (2012) using the software SEVAP also found poor performance of Jensen-Haise methodology for estimation of ET in Mato Grosso do Sul.

The method Makkink, among all tested methods, showed the largest ESE (Table 3). We expected the better performance of Makkink method, since it is derived from the Penman-Monteith. Possibly the effect of wind speed of Minas Gerais state, which does not include the method, has been the factor responsible for wretched estimated ET, similar to observations made by Magalhães; Cunha (2012), evaluating this method in the Mato Grosso do Sul state, Turco; Perecin; Pinto Jr. (2008) in the São Paulo state and Araújo; Costa; Santos (2007) also found in Roraima state underperforming the Makkink method. However, the states of Paraíba (SILVA et al., 2005), Rio de Janeiro (MENDONÇA et al., 2003) and Pará (SILVA; COSTA, 2000), this method showed excellent accuracy in the estimation of ET, when compared to the standard method. In turn, Tabari (2010) evaluated this method on four different climatic types, in Iran. The results showed that the method of Makkink had the worst performance among the methods studied. The author reports that this method has good performance in regions of cold, damp weather, and with this, justified his low performance for estimation of ET in the Minas Gerais state.

Nucleus,v.12,n.1,abr.2015 


\section{CONCLUSION}

The Hargreaves-Samani method should be preferred and used only when have air temperature data.

The Jensen-Haise and Makkink methodologies should not be used to estimate ET in Minas Gerais state.

\section{ACKNOWLEDGMENT}

The Conselho Nacional de Desenvolvimento Científico e Tecnológico (CNPq) for granting the scientific initiation scholarship to the first author.

\section{REFERENCES}

ALENCAR, L. P.et al. Comparação de diferentes métodos de estimativa diária da evapotranspiração de referência para a região de Uberaba. Revista Brasileira de Ciências Agrárias, Recife, v. 6, n. 2, p. 337343, 2011.

ALLEN, R. G.et al. Operational estimates of reference evapotranspiration. Agronomy Journal, Madison, v. 81, n. 4 , p. $650-662,1989$.

ALLEN, R. G.et al. Crop evapotranspiration: guidelines for computing crop water requirements. Rome: FAO, 1998. 300 p. (Irrigation and Drainage Paper, 56).

ARAÚJO, W. F.; COSTA, S. A. A.; SANTOS, A. E. Comparação entre métodos de estimativa da evapotranspiração de referência (ET0) para Boa Vista, RR. Caatinga, Mossoró, v. 20, n. 4, p. 84-88, 2007.

BACK, A. J. Desempenho de métodos empíricos baseados na temperatura do ar para a estimativa da evapotranspiração de referência em Urussanga, SC. Irriga, Botucatu, v. 13, n. 4, p. 449-466, 2008.

BARROS, V. R.et al. Avaliação da evapotranspiração de referência na região de Seropédica, Rio de Janeiro, utilizando lisímetro de pesagem e modelos matemáticos. Revista Brasileira de Ciências Agrárias, Recife, v. 4, n. 2, p. 198-203, 2009.

BERLATO, M. A.; MOLION, L. C. B. Evaporação e evapotranspiração. Porto Alegre: IPAGRO/Secretaria de Agricultura, 1981. 95 p. (Boletim Técnico, 7).

BIDLAKE, E. R. Evapotranspiration and canopy resistance at an undeveloped prairie in a humid subtropical climate. Journal of the American Water Resources Association, Washington, v. 38, n. 1, p. 197-211, 2002.

BRAGANÇA, R.et al. Estudo comparativo da estimativa da evapotranspiração de referência no período chuvoso para três localidades no Estado do Espírito Santo. Idesia, Arica, v. 28, n. 2, p. 21-29, 2010.

BURMAN, R. D.et al. Water requeriments. In: JENSEN, M. E. Design operation of farm irrigation system. Saint Joseph: ASAE, 1983. p. 189-232.

CAMARGO, A. P.; SENTELHAS, P. C. Avaliação do desempenho de diferentes métodos de estimativa da evapotranspiração potencial no estado de São Paulo. Revista Brasileira de Agrometeorologia, Santa Maria, v. 5, n. 1, p. 89-97, 1997. 
CARVALHO, L. G.et al. Evapotranspiração de referência: Uma abordagem atual de diferentes métodos de estimativa. Pesquisa Agropecuária Tropical, Goiânia, v. 41, n. 3, p. 456-465, 2011.

CAVALCANTE Jr., E. G.et al. Métodos de estimativa da evapotranspiração de referência para as condições do semiárido Nordestino. Semina, Londrina, v. 32, n. suplemento, p. 1699-1708, 2011.

COHEN, J. Statistical power analysis for the behavioral sciences. New Jersey: Lawrence Erlbaum, 1988. 569 p.

CUNHA, F. F.; MAGALHÃES, F. F.; CASTRO, M. A. Métodos para estimativa da evapotranspiração de referência para Chapadão do Sul - MS. Engenharia na Agricultura, Viçosa, v. 21, n. 2, p. 159-172, 2013.

DOLAN, T. J.et al. Evapotranspiration of a Flórida, USA, freshwater wetland. Journal of Hydrology, Amsterdam, v. 74, n. 1, p. 355-371, 1984.

DOORENBOS, J.; PRUITT, W. O. Crop water requirements. Rome: FAO, 1977. 143 p. (Irrigation and Drainage paper, 24).

JABLOUN, M.; SAHLI, A. Evaluation of FAO-56 methodology for estimating reference evapotranspiration using limited climatic data application to Tunisia. Agricultural Water Management, Amsterdam, v. 95, n. 6, p. 707-715, 2008.

JACOBS, J. M.; SATTI, S. R. Evaluation of reference evapotranspiration methodologies and AFSIRS crop water use simulation model. Gainesville: Department of Civil and Coastal Engineering, University of Florida, 2001. 114 p.

JENSEN, D. T.et al. Computation of ET0 under nonideal conditions. Journal of Irrigation and Drainage Engineering, New York, v. 123, n. 5, p. 394-400, 1997.

JENSEN, M. E.; BURMAN, R. D.; ALLEN, R. G. Evapotranspiration and irrigation water requeriments. New York: ASCE, 1990. 332 p.

KISI, O. Modeling monthly evaporation using two different neural computing techniques. Irrigation Science, New York, v. 29, n. 2, p. 417-430, 2009.

KISI, O.; ALI BABA, A. P.; SHIRI, J. Generalized neurofuzzy models for estimating daily pan evaporation values from weather data. Journal of Irrigation and Drainage Engineering, New York, v. 138, n. 4, p. 349-362, 2012.

LIANG, L.; LI, L.; LIU, Q. Temporal variation of reference evapotranspiration during 1961-2005 in the Taoer River basin of Northeast China. Agricultural and Forest Meteorology, Amsterdam, v. 150, n. 2, p. 298-306, 2009.

LÓPEZ-URREA, R.et al. Testing evapotranspiration equations using lysimeter observations in a semiarid climate. Agricultural Water Management, Amsterdam, v. 85, n. 1, p. 15-26, 2006.

MAGALHÃES, F. F.; CUNHA, F. F. Desempenho do software SEVAP na estimativa da evapotranspiração no Estado de Mato Grosso do Sul. Revista Agrarian, Dourados, v. 5, n. 16, p. 151160, 2012.

MARCUZZO, F. F. N.; ARANTES, E. J.; WENDLAND, E. Avaliação de métodos de estimativa de evapotranspiração potencial e direta para a região de São Carlos-SP. Irriga, Botucatu, v. 13, n. 3, p. 323338,2008 
MENDONÇA, E. A.; DANTAS, R. T. Estimativa da evapotranspiração de referência no município de Capim, PB. Revista Brasileira de Engenharia Agrícola e Ambiental, Campina Grande, v. 14, n. 2, p. 196-202, 2010.

MENDONÇA, J. C.et al. Comparação entre métodos de estimativa da evapotranspiração de referência (ET0) na região Norte Fluminense, RJ. Revista Brasileira de Engenharia Agrícola e Ambiental, Campina Grande, v. 7, n. 2, p. 275-279, 2003.

OLIVEIRA, R. A.; TAGLIAFERRE, C.; SEDIYAMA, G. C.; MATERAM, F. J. V.; CECON, P. R. Desempenho do Irrigâmetro na estimativa da evapotranspiração de referência. Revista Brasileira de Engenharia Agrícola e Ambiental, Campina Grande, v. 12, n. 2, p. 166-173, 2008.

PENMAN, H. L. Vegetation and hydrology. Harpenden: Commonwealth Bureau of Soils, 1963. 125 p. (Technical Communication, 53).

PEREIRA, A. R.; VILLA NOVA, N. A.; SEDIYAMA, G. C. Evapo(transpi)ração. 1.ed. Piracicaba: FEALQ, 1997. 183 p.

PEREIRA, D. R.et al. Desempenho de métodos de estimativa da evapotranspiração de referência para a região da Serra da Mantiqueira, MG. Ciência Rural, Santa Maria, v. 39, n. 9, p. 2488-2493, 2009.

REIS, E. F.; BRAGANÇA, R.; GARCIA, G. O. Estudo comparativo da estimativa da evapotranspiração de referência para três localidades do Estado do Espírito Santo no período seco. Idesia, Arica, v. 25, n. 3, p. 75-7854, 2007.

SAHOO, B.; WALLING, I.; DEKA, B. C.; BHATT, B. P. Standardization of reference evapotranspiration models for a sub-humid Valley Rangeland of Eastern Himalayas. Journal of Irrigation and Drainage Engineering, New York, v. 138, n. 10, p. 880-895, 2012.

SANIJ, H. D.; YAMAMOTO, T.; RASIAH, V. Assessment of evapotranspiration estimation models for use in semi-arid environments. Agricultural Water Management, Amsterdam, v. 64, n. 1, p. 91-106, 2004.

SILVA, M. M.; COSTA, A. C. L. Estudo comparativo da evapotranspiração em área de floresta de manguezal na região Bragantina-PA. In: CONGRESSO BRASILEIRO DE METEOROLOGIA, 11, 2000, Rio de Janeiro. Anais... Rio de Janeiro: CBM, 2000. p. 418-421.

SILVA, V. J.et al. Desempenho de diferentes métodos de estimativa da evapotranspiração de referência diária em Uberlândia, MG. Bioscience Journal, Uberlândia, v. 27, n. 1, p. 95-101, 2011.

SILVA, V. P. R.et al. Desenvolvimento de um sistema de estimativa da evapotranspiração de referência. Revista Brasileira de Engenharia Agrícola e Ambiental, Campina Grande, v. 9, n. 4, p. 547-553, 2005.

SOUZA, A. P.et al. Estimativas da evapotranspiração de referência em diferentes condições de nebulosidade. Pesquisa Agropecuária Brasileira, Brasília, v. 46, n. 3, p. 219-228, 2011.

SYPERRECK, V. L. G.et al. Avaliação de desempenho de métodos para estimativas de evapotranspiração de referência para a região de Palotina, Estado do Paraná. Acta Scientiarum Agronomy, Maringá, v. 30, n. 5, p. 603-609, 2008.

TABARI, H. Evaluation of reference crop evapotranspiration equations in various climates. Water Resource Management, Amsterdam, v. 24, n. 10, p. 2311-2337, 2010.

TAGLIAFERRE, C.et al. Estudo comparativo de diferentes metodologias para determinação da evapotranspiração de referência em Eunápolis-BA. Caatinga, Mossoró, v. 23, n. 1, p. 103-111, 2010. 
TURCO, J. E.; PERECIN, D.; PINTO Jr., D. L. Influência da acurácia de instrumentos de medidas na comparação de métodos de estimativa da evapotranspiração de referência. Irriga, Botucatu, v. 13, n. 1, p. 63-80, 2008.

WILLMOTT, C. J.et al. Statistics for the evaluation and comparison of models. Journal of Geophysical Research, Ottawa, v. 90, n. 5, p. 8995-9005, 1985.

XU, C-Y.; CHEN, D. Comparison of seven models for estimation of evapotranspiration and groundwater recharge using lysimeter measurement data in Germany. Hydrological Processes, Chichester, v. 19, n. 18, p. 3717-3734, 2005.

YODER, R. E.; ODHIAMBO, L. O.; WRIGHT, W. C. Evaluation of methods for estimating daily reference crop evapotranspiration at a site in the humid Southeast United States. Applied Engineering in Agriculture, Saint Joseph, v. 21, n. 2, p. 197-202, 2005. 